\title{
Rachis Lignification of Couroupita guianensis Aubl.
}

\author{
Monique de Moura Gurgel, Heber dos Santos Abreu, Gisely de Lima Oliveira, \\ Carlos Henrique Rocha Gonçalves, Tatiana de Felice Elias, Juliana Bernardo Amodei
}

Departamento de Produtos Florestais, Instituto de Florestas, Universidade Federal Rural do Rio de Janeiro - UFRRJ

\begin{abstract}
The aim of this study was to substantiate the possible influence of gravity on the lignin content in the rachis of Couroupita guianensis Aubl., since it grows in favor of gravitational forces. Chemical analysis, medium infrared (FTIR) spectroscopy and microspectroscopy were conducted, coupled with supporting images obtained from an optical microscope. The rachis lignin content was $5.56 \%$, composed of both syringyl and guaiacyl units; the latter being predominant, showing that the gravity force influenced the lignin process when compared with lignin content of main stem, $17 \%$.
\end{abstract}

Keywords: gravity, lignin, infrared spectroscopy.

\section{Lignificação da raque de Couroupita guianensis Aubl.}

\begin{abstract}
RESUMO
O objetivo deste estudo foi substanciar a possível influência da gravidade no teor da lignina em raque de Couroupita guianensis Aubl., visto que esta tem seu crescimento a favor da força gravitacional. Análise química, microespectroscopia e espectroscopia no infravermelho médio foram realizadas com apoio das imagens obtidas no microscópio óptico. O teor de lignina das raques foi $5,56 \%$, composto por duas unidades siringil e guaiacil; este último mostrouse predominante, indicando que a força da gravidade influenciou o processo de lignificação quando comparado com o teor de lignina da tronco principal de $17 \%$.
\end{abstract}

Palavras-chave: gravidade, lignina, espectroscopia no infravermelho.

\section{INTRODUCTION}

The advent of lignin on the Earth's surface has been a theoretically speculated subject of evolutionary nature, which explains the existence of lignin owing to the necessity for plants to grow vertically. Lewis \& Sarkanen (1998) described the evolutionary process beginning with green algae. However, a recent divergent dichotomy has arisen, giving way to heightened discussion as a result of the discovery of lignin, chiefly consisting of syringyl, in red algae. (Martone et al., 2009).
The occurrence of lignin in plant cell walls rests in the explanation of upward growth, water conduction, resistance and defense against microorganisms, amongst other functions. The influence of gravity in the lignification process was reported from experiments conducted under microgravity conditions (Stutter et al., 2006). Some laboratory experiments portraying conditions that simulate the gravity effect demonstrated the consequent accumulation of lignin in cell walls (Allen et al., 2009). 
The formation process of a plant is determined by genetics and it is influenced by environmental pressures, such as gravity. In response to these environmental stimuli, trees have the ability to reorient their axes, branches, or trunk in order to reestablish the equilibrium by developing a special type of tissue. (Du \& Yamamoto, 2007; Dérjardin et al., 2010).

The characteristics and location of such tissue differ between groups of plants. In gymnosperms, the tissue is called compression wood, developing in the undersides of branches or twigs. In angiosperms, it is called tension wood, occurring in the upper region. An increase in lignification occurs in the lower stem or branch in both groups (Wardrop, 1965). Plants growing under the influence of gravity usually develop tissues with chemical compositions and physical properties separate from tissues encountered on the main stem. The medium infrared (FTIR) spectroscopy allows for a rapid and non-destructive analysis. It has the ability to show interactions between macromolecules and it is a tool which may be applied to identify the composition of plant cell walls, as lignin and polysaccharide compounds (Dence, 1992). Lignin analysis by infrared has been a tool for identification of lignin content and its composition in wood and other lignocellulosics materials. The experimental technique of Diffuse Reflectance seems to be a precise spectrum for content determination. Computer software technique, such as convolution, was used for $\beta-\mathrm{O}-4$ bond determination in tropical wood (Abreu, 1997).

The study of plant parts with growth in the direction of gravitational forces showed the production of chemical changes, principally concerning lignin content. Gravity stimulates the accumulation of lignin, and the formation of other substances in the supporting tissues. In this regard, the purpose of this study was to fully substantiate the expedient influence of gravity on the rachis lignification of the Couroupita guianensis Aubl. tree.

\section{MATERIAL AND METHODS}

\subsection{Sampling}

Rachises of Couroupita guianensis Aubl., popularly known as "abricó de macaco", were collected at the campus of "Universidade Federal Rural do Rio de Janeiro' in Seropedica, State of Rio de Janeiro. The samples were used as anatomic cuts and for chemical analysis. A whole rachis was used, divided into four distinct regions, namely: the upper and lower regions, near the stem and fruit (Figure 1), in a total of five samples per region.

\subsection{Optical microscopy}

Cross-sections of $10 \mu \mathrm{m}$ thickness were obtained in a microtome (MICROM HM450), fixed with FAA (50 mL 40\% formaldehyde, $50 \mathrm{~mL}$ glacial acetic acid, $90 \mathrm{~mL} \mathrm{50 \%} \mathrm{ethanol)} \mathrm{for} \mathrm{two} \mathrm{days} \mathrm{and} \mathrm{subjected} \mathrm{to}$ two methods of staining.

The first consisted of staining with an alcoholic solution of Safranin-O (1 g/65 mL 100\% ethanol and $30 \mathrm{~mL}$ distilled water) for two hours, washed three times in $85 \%$ ethanol for 5 minutes, stained once more using an alcoholic solution of Astra Blue (1 g.100 $\mathrm{mL}^{-1} 100 \%$ ethanol and $5 \mathrm{ml}$ distilled water) for 3 minutes, then quickly washed in absolute ethanol (95\%). Safranin was used to identify lignin and Astra blue, polysaccharides (Vasquez Cooz \& Meyer, 2002).

For the second method, the sections were stained with $2 \%$ Safranin-O for 24 hours, and then quickly washed in distilled water and $70 \%$ ethanol as recommended by Jensen (1962).

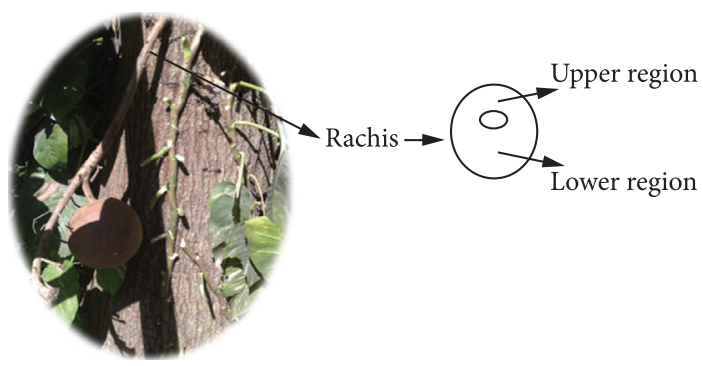

Figure 1. Disposition of the rachis of Couroupita guianensis Aubl. The studied areas are in highlight.

Figura 1. Disposição das raques de Couroupita guianensis Aubl. As áreas estudadas estão em destaque. 
The sections were observed in an optical microscope (Olympus BX51) coupled to a digital image analysis system (Cell ${ }^{*}$ Family).

\subsection{Medium infrared (FTIR) microspectroscopy}

Anatomical cross-sections of $14 \mu \mathrm{m}$ thickness were obtained using a microtome (MICROM HM450), they were used to generate, in loco, IR spectra through a microscope coupled to an IR spectrometer (Varian 640-IR FT-IR), in order to characterize and localize the presence of lignin in the tissues.

To this end, natural cuts treated with $1 \% \mathrm{NaOH}$; $\%$; which allow better visualization of the organic groups, were frozen in liquid nitrogen for 30 seconds, and then dried between two glass slides for 12 hours in a lyophilizer (Terroni - Enterprise Model). Once dried, the samples were placed on $\mathrm{KBr}$ microscope slides and analyzed, by diffuse reflectance, at a wavenumber range of 700-4000 $\mathrm{cm}^{-1}$, resolution of $2 \mathrm{~cm}^{-1}$ and 128 scans.

\subsection{Chemical analysis}

For chemical analysis, the rachis samples acquired from the stems were air dried and ground to sawdust using a Willey mill. The resulting powder was extracted with cyclohexane, ethyl acetate and methanol solvents in a soxhlet extractor, and each extraction was completed over an uninterrupted 24 hours period for each of the solvents (Abreu et al., 2006). The same was performed with the sample wood of diameter at breast height (DBH) of main trunk from the same tree where the rachis was collected. The extractive-free material was used to determine the lignin content and for the infrared analysis.

The Klason method was applied for the determination of the lignin content. To this end, $300 \mathrm{mg}$ of extractive-free dried material was transferred to a test tube, gradually adding $3 \mathrm{~mL}$ of $72 \%$ sulfuric acid, homogenized by continuous stirring for one minute, and placed in a water bath at a temperate ranging between $25-30{ }^{\circ} \mathrm{C}$ for 1 hour. Subsequently, the material was transferred to a volumetric flask, to which $84 \mathrm{~mL}$ of distilled water was added. The solution was brought to boil at reflux for 4 hours. The residue was then filtered, washed with hot water, and dried in oven at a temperature of $103 \pm 2{ }^{\circ} \mathrm{C}$ (Dence, 1992).

\subsection{Infrared spectroscopy}

The extractive-free material was ground in a stainless steel mill (Marconi) and $2 \mathrm{mg}$ of this sample was lyophilized for 12 hours. The sample was subsequently homogenized in $100 \mathrm{mg}$ of $\mathrm{KBr}$ into a mortar, and then molded into a pellet which was used to record the spectra data in a Varian 640-IR FT-IR Spectrometer, in transmittance mode with a resolution of $4 \mathrm{~cm}^{-1}, 128$ scans, and wavenumber between 4,000-400 $\mathrm{cm}^{-1}$.

\section{RESULTS AND DISCUSSION}

In the cross-sections, it was observed that fibers showed varying shapes and compositions, differing between tension wood and the tissue of the lower rachis region (Figures $2 \mathrm{a}$ and $2 \mathrm{~b}$ ). A markedly red fibrous zone can be observed in Figure 2b; and in Figure $2 \mathrm{~d}$, with this area magnified, it is possible to observe less organized fibers than in the tension wood (Figure 2c), now visually narrower.

Tension wood tends to possess high quantities of cellulose, being less lignified than normal wood (Pilate et al., 2004), demonstrating an increase in the proportion of fibers containing thick walls, as seen in Figures $2 \mathrm{~d}$ and $3 \mathrm{~d}$.

By double staining with Safranin-O/Astra Blue, it was possible to observe a thick layer in the inner secondary wall, suggesting the presence of gelatinous fibers developed mainly in the tension wood, as indicated by the arrows in Figure 3d. According to Pilate et al. (2004), this layer presents itself as less lignified and/or with a higher content of syringyl units, which is consistent with what is essentially observed (violet). In contrast, layers S1 and S2 of the secondary wall are generally narrower, having a higher lignin content, observed in Figure 3d with a pinkish color (Timell, 1969; Joseleau et al., 2004).

Studies indicated that there is an increased Syringyl/Guaiacyl (S/G) ratio in tension wood and, therefore, visually, the blue-violet layer of gelatinous 

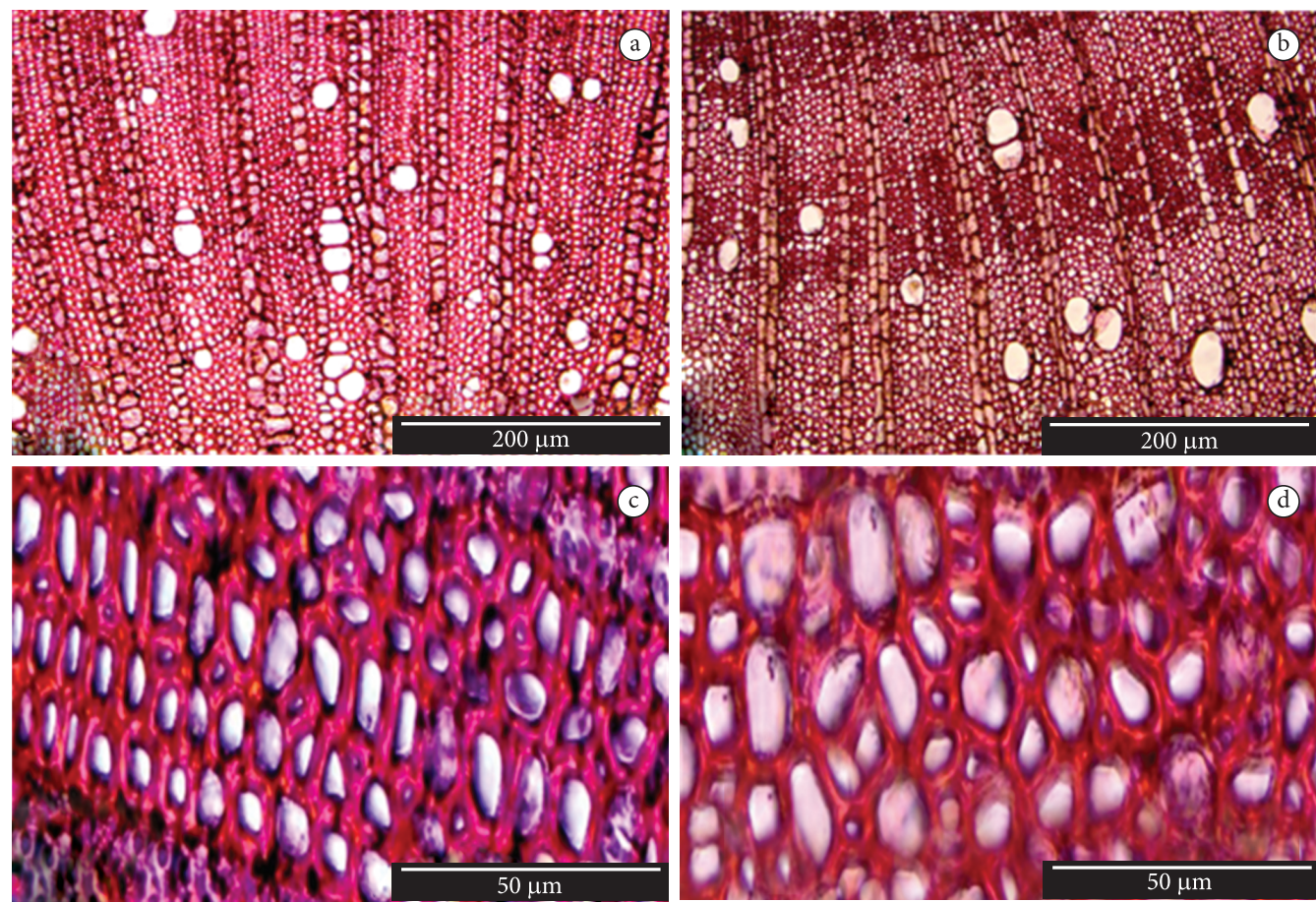

Figure 2. Cross-sections of the rachis of Couroupita guianensis Aubl., stained with Safranin-O: a, c) Upper region or tension wood, b, d) Lower or opposing region to the tension wood.

Figura 2. Seções transversais das raques de Couroupita guianensis Aubl., coradas com Safranina-O: a,c) Região superior ou tecido de tensão, b, d) Região inferior ou oposta ao tecido de tensão.
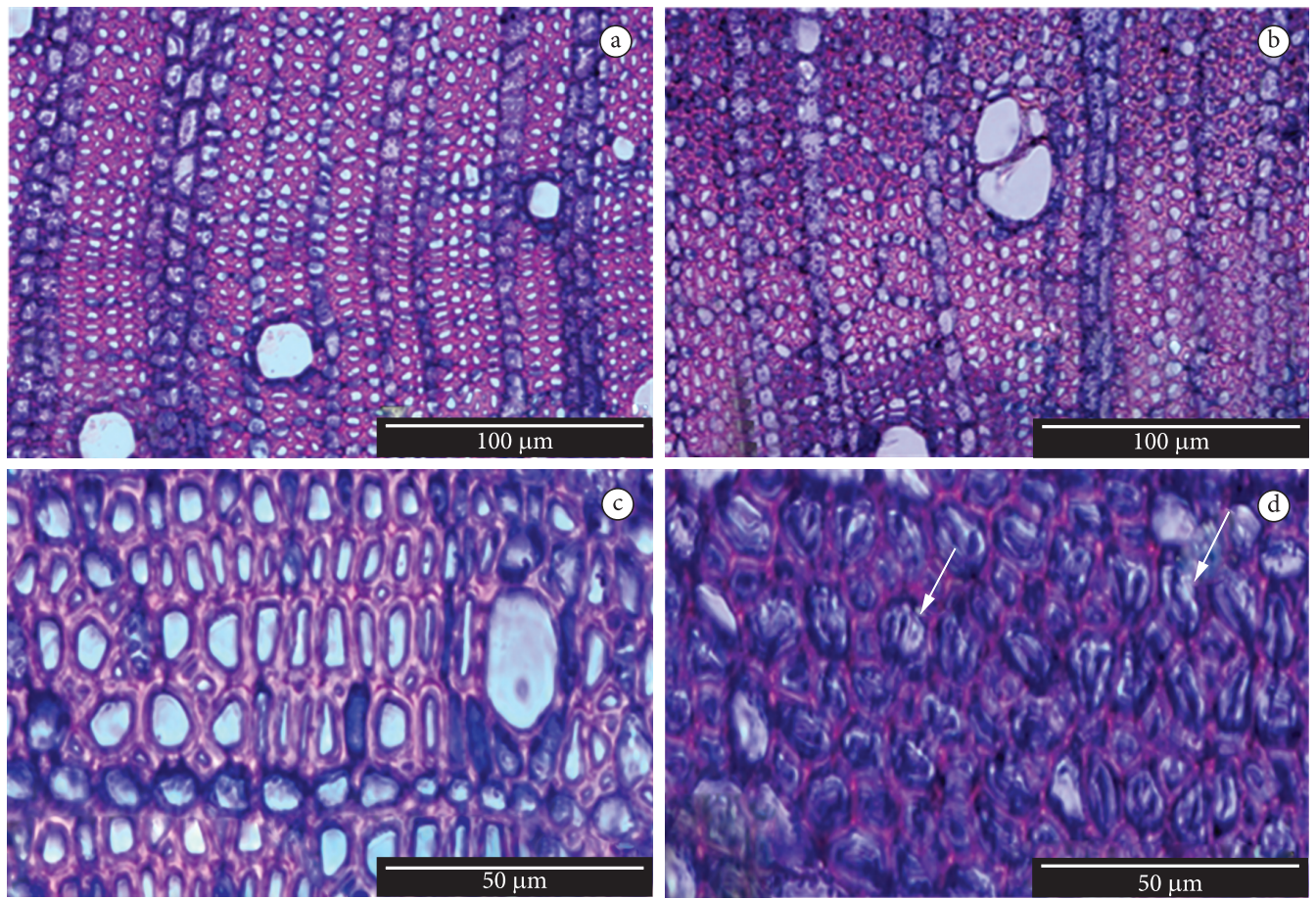

Figure 3. Cross-sections of the rachis of Couroupita guianensis Aubl. stained with Safranin-O/Astra Blue: a, c) Upper region or tension wood, b, d) Lower or opposing region to the tension wood.

Figura 3. Seções transversais das raques de Couroupita guianensis Aubl. coradas com Safranina-O/ Azul de Astra: a, c) Região superior ou tecido de tensão, b, d) Região inferior ou oposta ao tecido de tensão. 
fibers indicates a greater amount of syringyl units (Yoshida et al., 2002; Aoyama et al., 2001).

The secondary wall of fibers usually contains lignin of the guaiacyl and syringyl types. Astra Blue (affinity to the syringyl unit) staining promoted a violet hue, as demonstrated in Figure 3c. Figure 3b provides strong evidence of syringyl lignin in the darker band.

In all five sampled regions of rachis of Couroupita guianensis Aubl, the infrared spectra of the lignocellulosic material (ground material) indicated signs of guaiacyl/syringyl lignins (1329-1252 $\left.\mathrm{cm}^{-1}\right)$, as shown in Figure 4.

Figure 4 illustrates signals corresponding to the guaiacyl ring, (with contributions from the $\mathrm{C}=\mathrm{O}$ stretching), 1252 to $1254 \mathrm{~cm}^{-1}$. The signals corresponding to the presence of the syringyl unit, with assistance from the $\mathrm{C}=\mathrm{O}$ stretching, and condensed structures were: 1328 to $1330 \mathrm{~cm}^{-1}$ (Abreu, 1994). It was noted that guaiacyl lignin was prevalent in all samples, where the spectra showed signals in $1252 \mathrm{~cm}^{-1}$ higher than $1328 \mathrm{~cm}^{-1}$.

The spectra of the cross-sections in the upper rachis region of the natural wood indicate the complexities and non-possibility to clearly identify the presence of lignin, as shown in Figure 5. In Figures $5 b, c$ and $d$, the signals corresponding to the lignin presence faintly demonstrate their intensity, in smaller proportions, when compared to the spectra of the ground material illustrated in Figure 4.

The lignin content of the entire rachis, upper region near the trunk and the near the fruit, lower region near the trunk and near the fruit was 5.40, $5.79,5.58,5.89,5.66 \%$, respectively - each treatment repeated five times. The low lignin content of the rachis, averaging $5.56 \%$, may have contributed to a lower level of absorption associated with a microscopy technique of low resolution. Transmittance mode (Figure 4) was used in the conventional spectrum. These spectra showed more evident signs than the spectra in reflectance mode (FTIR microscopy) (Figure 5), because the analyzed homogenized material in powder form showed presence of lignin in the material diluted in $\mathrm{KBr}$, while tissue showed deposition of lignin on discontinuous layer of $\mathrm{KBr}$.

It is also important to remark that the techniques used to obtain the spectra illustrated in Figures 4 and

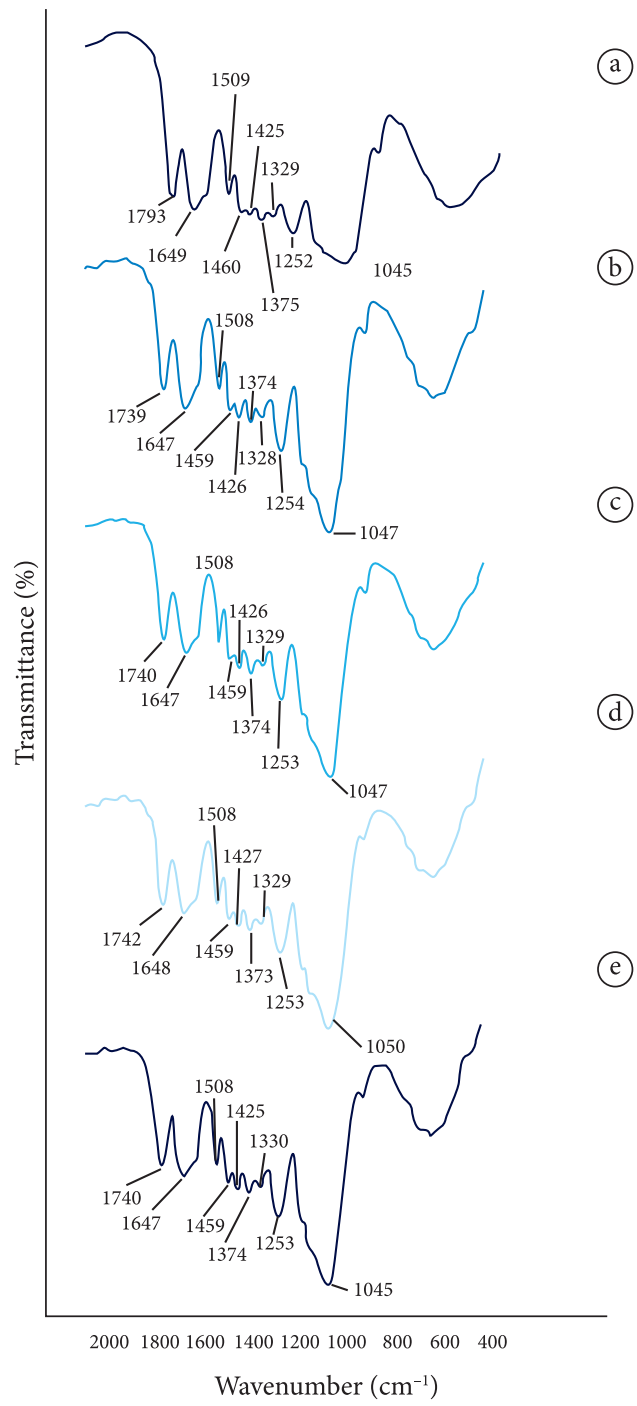

Figure 4. Infrared spectra of (powder) woody material of the rachis of Couroupita guianensis Aubl., extracted with cyclohexane, ethyl acetate and methanol solvents. a) entire rachis, b) upper region near the trunk, c) upper region near the fruit, d) lower region near the trunk, e) lower region near the fruit.

Figura 4. Espectros no infravermelho do material na forma de pó da raque de Couroupita guianensis Aubl., extraída com ciclohexano, acetato de etila e metanol. a) Raque inteira, b) Região superior próxima ao tronco, c) Região superior próxima ao fruto, d) Região inferior próxima ao tronco, e) Região inferior próxima ao fruto.

5 were different. The techniques used for microscopy can cause distortions in the spectra due to the direct use of the cross section of rachis tissues. In the case of rachis in powder form, as it is diluted in $\mathrm{KBr}$, the bands provided are more reliable, both in wavelength as well as in time. 


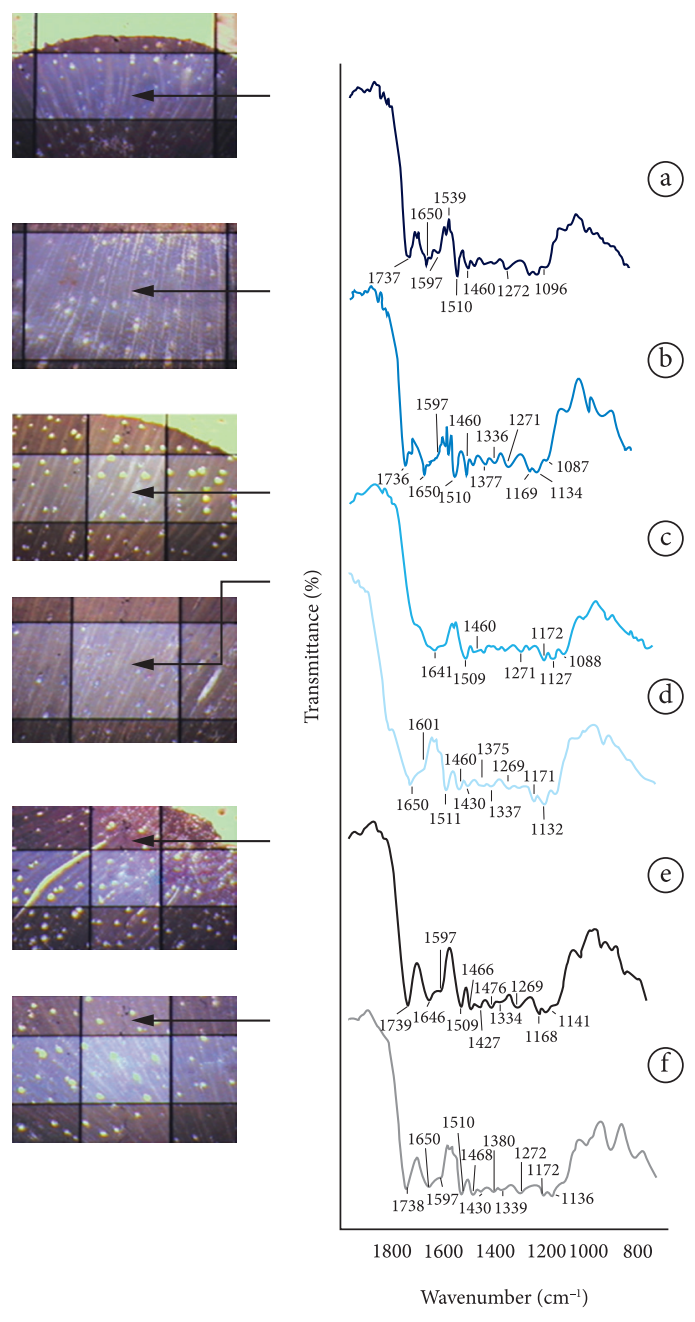

Figure 5. Photos and infrared spectra of the crosssection regions of the rachis of Couroupita guianensis Aubl. obtained with a microscope, a) Natural section of upper region, b) Natural section of lower region, c) Section treated with $\mathrm{NaOH} 1 \%$ of upper region, d) Section treated with $\mathrm{NaOH} 1 \%$ of lower region, e) Section treated with acetone of upper region, f) Section treated with acetone of lower region.

Figura 5. Fotos e espectros obtidos por infravermelho através de um microscópio nas regiões da seção transversal da raque de Couroupita guianensis Aubl., a) Corte ao natural da região superior, b) Corte ao natural da região inferior, c) Corte tratados com $\mathrm{NaOH}$ $1 \%$ da região superior, d) Corte tratados com $\mathrm{NaOH}$ $1 \%$ da região inferior, e) Cortes tratados com acetona da região superior, f) Cortes tratados com acetona da região inferior.

The low lignin content in the rachis, comparable to the wood of main trunk $\mathrm{DBH}, 17 \%$, may be due to its vertical negative growth (for the force of gravity). It may have caused the deactivation of the enzyme complex activity that regulates the rachis lignification. This was observed in plants which grow in microgravity systems, showing changes in the lignification process (Allen et al., 2009).

The recorded signals at 1737 and $1736 \mathrm{~cm}^{-1}$ did not appear in the sections treated with $1 \% \mathrm{NaOH}$. These signals correspond to the stretching of ester or carboxylic acid carbonyls, existent in hemicelluloses (Orton et al., 2004). This treatment is recommended to eliminate impurities (phenols and hemiceluoses) in order to reduce the interference of other absorptions in the analysis of lignin (Dence, 1992).

\section{CONCLUSION}

The rachis tissue of Couroupita guianensis Aubl. presented characteristics of tension wood, which is indicative of gelatinous fibers. The infrared spectra recorded in the conventional way revealed the existence of guaiacyl and syringyl lignin, predominantly comprising guaiacyl units, although the spectra recorded in reflectance only provided some evidence.

The total lignin content was $5.56 \%$, demonstrating a minor effect of gravitational forces on the tissue, seemingly discouraging the actions of hormones and enzymes in the lignification process.

\section{ACKNOWLEDGEMENTS}

The authors are grateful to CAPES, for the scholarship granted to the first author; to the Wood Quality Nucleus Research, for the lending of the microtome; and to FAPERJ/CAPES, for the equipment made available at the Wood Chemistry Laboratory of the Forest Product Department of 'Universidade Federal Rural do Rio de Janeiro'.

\section{SUBMISSION STATUS}

Received: 15/02/2011

Accepted: 17/08/2011

Abstract published online: 30/08/2011

Full paper published: 30/09/2011 


\section{CORRESPONDENCE TO}

\section{Monique de Moura}

Departamento de Produtos Florestais, Instituto de Florestas,

Universidade Federal Rural do Rio de Janeiro UFRRJ, BR 465, Km 07, Seropédica, RJ, Brasil

e-mail: monique_floresta@yahoo.com.br

\section{REFERENCES}

Abreu HS. Biossíntese da lignificação. Editora Universidade Rural; 1994. 60 p.

Abreu HS. Estimativa por infravermelho da concentração da unidade estrutural $\beta$-O-4 em ligninas de angiospermas tropicais. Química Nova 1997; 20(6):592-598. http://dx.doi.org/10.1590/S010040421997000600005

Abreu HS, Carvalho AM, Monteiro MBO, Pereira RPW, Silva HR, Souza KCA. et al. Métodos de análise em química da madeira. Floresta e ambiente 2006; 20.

Allen J, Bisbee PA, Darnell RL, Kuang A, Levine LH, Musgrave ME. et al. Gravity control of growth form in Brassica rapa and Arabidopsis thaliana (brassicaceae): consequences for secondary metabolism. American Journal of Botany 2009; 96(3):652-660. PMid:21628221. http://dx.doi.org/10.3732/ajb.0800261

Aoyama W, Matsumura A, Tsutsumi Y, Nishida T. Lignification and peroxidase in tension wood of Eucalyptus viminalis seedlings. Journal Wood Science. 2001; 47:419-424. http://dx.doi.org/10.1007/ BF00767892

Dence CW. The determination of lignin. In: Lin SY, Dence CW, editores. Methods in lignin chemistry. Springer-Verlag; 1992. p. 33-61.

Dérjardin AD, Laurans F, Arnaud D, Breton C, Pilate G, Leplé J. Wood formation in Angiosperms. Plant biology and pathology 2010; 325-334.

Du S, Yamamoto F. An overview of biology of reaction wood formation. Journal of Integrative Plant Biology 2007; 49:131-143. http://dx.doi.org/10.1111/j.17447909.2007.00427.x

Jensen WA. Botanical Histochemistry: Principle and Practice. San Francisco: Freeman WH \& Co.; 1962. p. 71-91,
Joseleau JP, Imai T, Kuroda K, Rue LK. Detection in situ and characterization of lignin in the G-layer of tension wood fibres of Populus deltoids. Planta 2004; 219:338345. PMid:15067547. http://dx.doi.org/10.1007/s00425004-1226-5

Lewis NG, Sarkanen S. Lignin and Lignan Biosynthesis. Washington: American Chemical Society; 1998. (ACS Symposium Series).

Martone PT, Lu F, Somerville C, Estevez J, Ruel K, Denny MW. et al. IntroduçãoDiscovery of Lignin in Seaweed Reveals Convergent Evolution of CellWall Architecture. Current Biology 2009; 19:169175. PMid:19167225. http://dx.doi.org/10.1016/j. cub.2008.12.031

Orton CR, Parkinson DY, Evans PD, Owen NL. Fourier Transform Infrared Studies of Heterogeneity, Photodegradetion, and Lignin / Hemicellulose Ratios Within Hardwoods and Softwoods. Applied Spectroscopy 2004; 58(11). PMid:15606929. http:// dx.doi.org/10.1366/0003702042475385

Pilate G, Chabbert B, Yoshinaga A, Leplé JC, Laurans F, Lapierre C. et al. Lignification and tension wood. Plant biology and pathology 2004; 327:889-901.

Stutter GW, Monje O, Hatfield RD, Paul AL, Ferl RJ, Simone CG. Microgravity effects on leaf morphology, cell structure, carbon metabolism and mRNA expression of dwarf wheat. Planta 2006; 1038-1049. PMid:16708225. http://dx.doi.org/10.1007/s00425-0060290-4

Timell TE. The chemical composition of tension wood. Svensk Papperstidn 1969; 72:173-181.

Vasquez $\mathrm{Cooz}$ I, Meyer RW. A differential staining method to identify lignified and unlignified tissues. Biotechnic \& Histochemisty 2002; 77:277- 282. PMid:12564601.

Wardrop AB. The formation and function of reaction wood. In: Coté WA, editor. Cellular ultrastructure of woody plants. Syracuse University Press; 1965. p. 371-390.

Yoshida M, Ohta H, Okuyama T. Tensile growth stress, lignin distribution in the cell walls of black locust (Robinia pseudo- acacia). Journal Wood Science 2002; 48:99-105. http://dx.doi.org/10.1007/BF00767285 